\title{
A new method for calculating number concentrations of cloud condensation nuclei based on measurements of a three-wavelength humidified nephelometer system
}

\author{
Jiangchuan Tao ${ }^{1,2}$, Chunsheng Zhao ${ }^{2}$, Ye Kuang ${ }^{1,2}$, Gang Zhao ${ }^{2}$, Chuanyang $\mathrm{Shen}^{2}$, Yingli Yu ${ }^{2}$, Yuxuan Bian ${ }^{3}$, and \\ Wanyun $\mathrm{Xu}^{3}$ \\ ${ }^{1}$ Institute for Environment and Climate Research, Jinan University, Guangzhou, China \\ ${ }^{2}$ Department of Atmospheric and Oceanic Sciences, School of Physics, Peking University, Beijing, China \\ ${ }^{3}$ State Key Laboratory of Severe Weather, Chinese Academy of Meteorological Sciences, Beijing, China
}

Correspondence: Chunsheng Zhao (zcs@pku.edu.cn)

Received: 14 June 2017 - Discussion started: 28 July 2017

Revised: 23 December 2017 - Accepted: 2 January 2018 - Published: 14 February 2018

\begin{abstract}
The number concentration of cloud condensation nuclei $(\mathrm{CCN})$ plays a fundamental role in cloud physics. Instrumentations of direct measurements of $\mathrm{CCN}$ number concentration $\left(N_{\mathrm{CCN}}\right)$ based on chamber technology are complex and costly; thus a simple way for measuring $N_{\mathrm{CCN}}$ is needed. In this study, a new method for $N_{\mathrm{CCN}}$ calculation based on measurements of a three-wavelength humidified nephelometer system is proposed. A three-wavelength humidified nephelometer system can measure the aerosol lightscattering coefficient $\left(\sigma_{\mathrm{sp}}\right)$ at three wavelengths and the lightscattering enhancement factor $(f \mathrm{RH})$. The Ångström exponent $(\AA)$ inferred from $\sigma_{\mathrm{sp}}$ at three wavelengths provides information on mean predominate aerosol size, and hygroscopicity parameter $(\kappa)$ can be calculated from the combination of $f \mathrm{RH}$ and $\AA$. Given this, a lookup table that includes $\sigma_{\mathrm{sp}}, \kappa$ and $\AA$ is established to predict $N_{\mathrm{CCN}}$. Due to the precondition for the application, this new method is not suitable for externally mixed particles, large particles (e.g., dust and sea salt) or fresh aerosol particles. This method is validated with direct measurements of $N_{\mathrm{CCN}}$ using a CCN counter on the North China Plain. Results show that relative deviations between calculated $N_{\mathrm{CCN}}$ and measured $N_{\mathrm{CCN}}$ are within $30 \%$ and confirm the robustness of this method. This method enables simpler $N_{\mathrm{CCN}}$ measurements because the humidified nephelometer system is easily operated and stable. Compared with the method using a CCN counter, another advantage of this newly proposed method is that it can obtain $N_{\mathrm{CCN}}$ at lower supersaturations in the ambient atmosphere.
\end{abstract}

\section{Introduction}

Cloud condensation nuclei $(\mathrm{CCN})$ are the aerosol particles that form cloud droplets by hygroscopic growth. CCN number concentration $\left(N_{\mathrm{CCN}}\right)$ plays a fundamental role in cloud microphysics and aerosol indirect radiative effect. In general, the direct measurement of $N_{\mathrm{CCN}}$ is achieved in a chamber under supersaturated conditions (Hudson, 1989; Nenes et al., 2001; Rose et al., 2008). Due to the requirement of high accuracies of working conditions like temperatures, vapors and flow rates in chambers, the direct measurement of $N_{\mathrm{CCN}}$ is complex and costly (Rose et al., 2008; Lathem and Nenes, 2011). Thus, developments of simplified measurements of $N_{\mathrm{CCN}}$ are required. In recent years, attention has been focused on measurements of aerosol optical properties (Jefferson, 2010; Ervens et al., 2007; Gasso and Hegg, 2003), which are simple and well developed (Covert et al., 1972; Titos et al., 2016). For aerosol population free of sea salt or dust, the accumulation mode aerosol not only dominates aerosol scattering ability but also contributes most to $N_{\mathrm{CCN}}$. Thus, the calculation of $N_{\mathrm{CCN}}$ based on measurements of aerosol optical properties is feasible and can facilitate $N_{\mathrm{CCN}}$ measurement.

There are methods for calculating $N_{\mathrm{CCN}}$ based on measurements of aerosol optical properties. For the first, $N_{\mathrm{CCN}}$ as well as the hygroscopicity parameter $(\kappa)$ can be calculated based on measurements of a humidified nephelometer system in combination with aerosol particle number size distribution (PNSD; Ervens et al., 2007; Chen et al., 2014). Thus addi- 
Table 1. Review of studies that have used aerosol optical parameters to infer $N_{\mathrm{CCN}}$.

\begin{tabular}{|c|c|c|c|c|c|}
\hline Campaign & Air mass & Parameter & Caveats & Results & Reference \\
\hline $\begin{array}{l}\text { ICARTT }^{1} \text { in the } \\
\text { northeastern USA } \\
\text { and Canada }\end{array}$ & Polluted air mass & $f$ RH and PNSD & $\begin{array}{l}N_{\mathrm{CCN}} \text { calculated with } \\
\text { aerosol hygroscopicity } \\
\text { constrained by } f(\mathrm{RH}) \text { and } \\
\text { PNSD. }\end{array}$ & $\begin{array}{l}N_{\mathrm{CCN}} \text { predicted at SS } \\
>0.3 \% \text { with a } 0.9 R^{2} .\end{array}$ & $\begin{array}{l}\text { Ervens et } \\
\text { al. (2007) }\end{array}$ \\
\hline $\begin{array}{l}\mathrm{HaChi}^{2} \text { on the } \\
\text { North China Plain }\end{array}$ & $\begin{array}{l}\text { Aged continental } \\
\text { air mass }\end{array}$ & PNSD and $f$ RH & $\begin{array}{l}\text { Similar to Ervens et } \\
\text { al. (2007). } N_{\mathrm{CCN}} \text { calcu- } \\
\text { lated with the hygroscop- } \\
\text { icity parameter constrained } \\
\text { by } f(\mathrm{RH}) \text { and PNSD. }\end{array}$ & $\begin{array}{l}\text { Slopes around } 1 \text { and } R^{2} \\
\text { around } 0.9 .\end{array}$ & $\begin{array}{l}\text { Chen et } \\
\text { al. (2014) }\end{array}$ \\
\hline $\begin{array}{l}\text { TARFOX }{ }^{3} \text { Atlantic } \\
\text { seaboard and ACE- } \\
2^{4}\end{array}$ & Polluted air mass & $\begin{array}{l}\begin{array}{l}\text { Aerosol volume re- } \\
\text { trieved from remote } \\
\text { sensing }\end{array} \\
\end{array}$ & $\begin{array}{l}N_{\mathrm{CCN}} \text { predicted from } \\
\text { aerosol volumes with em- } \\
\text { pirical number-to-volume } \\
\text { concentration ratio. }\end{array}$ & $\begin{array}{l}\text { Overestimated up to } 5 \\
\text { times. }\end{array}$ & $\begin{array}{l}\text { Gasso and } \\
\text { Hegg (2003) }\end{array}$ \\
\hline $\begin{array}{l}\text { ACE-2 in north- } \\
\text { eastern Atlantic }\end{array}$ & Diverse air mass & $\begin{array}{l}\text { Backscatter or extinction } \\
\text { profile. } \mathrm{CCN} \text { at the sur- } \\
\text { face. }\end{array}$ & $\begin{array}{l}N_{\mathrm{CCN}} \text { profile retrieved } \\
\text { from backscatter (or ex- } \\
\text { tinction) vertical profile } \\
\text { assuming their ratios are the } \\
\text { same as the ratio at surface, } \\
\text { which can be calculated by } \\
\text { backscatter (or extinction) } \\
\text { and } N_{\mathrm{CCN}} \text { measured at the } \\
\text { surface. }\end{array}$ & $\begin{array}{l}N_{\mathrm{CCN}} \text { predicted on most } \\
\text { days for } 0.1 \% \mathrm{SS} \text { and on } \\
20-40 \% \text { of the days at } \\
1 \% \mathrm{SS} \text {. }\end{array}$ & $\begin{array}{l}\text { Ghan and } \\
\text { Collins (2004) }\end{array}$ \\
\hline $\begin{array}{l}\mathrm{ARM}^{5} \text { Climate Re- } \\
\text { search Facility cen- } \\
\text { tral site at }\end{array}$ & $\begin{array}{l}\text { Continental air } \\
\text { mass }\end{array}$ & $\begin{array}{l}\text { Backscatter (or extinc- } \\
\text { tion) and } \mathrm{RH} \text { profile. }\end{array}$ & $\begin{array}{l}\text { Same as Ghan and } \\
\text { Collins (2004). }\end{array}$ & $\begin{array}{l}\mathrm{CCN} \text { variance explained } \\
\text { for } 25-63 \% \text { of }\end{array}$ & $\begin{array}{l}\text { Ghan et } \\
\text { al. }(2006)\end{array}$ \\
\hline $\begin{array}{l}\text { the Southern Great } \\
\text { Plains }\end{array}$ & & $f \mathrm{RH}$ and $\mathrm{CCN}$ at surface & & $\begin{array}{l}\text { all measurements at high } \\
\text { supersaturations }\end{array}$ & \\
\hline $\begin{array}{l}\text { TRACE-P }{ }^{6} \text { and } \\
\text { ACE-Asia }^{7}\end{array}$ & $\begin{array}{l}\text { Asian outflow over } \\
\text { the western Pacific }\end{array}$ & $\begin{array}{l}\text { Aerosol index (AI, the } \\
\text { product of ambient light } \\
\text { extinction and } \AA \text { ) }\end{array}$ & $\begin{array}{l}N_{\mathrm{CCN}} \text { predicted based on } \\
\text { empirical relationship } \\
\text { between } \mathrm{AI} \text { and } N_{\mathrm{CCN}} \text {. }\end{array}$ & $\begin{array}{l}\text { AI related well to CCN } \\
\text { only with suitably strati- } \\
\text { fied data. }\end{array}$ & $\begin{array}{l}\text { Kapustin et } \\
\text { al. (2006) }\end{array}$ \\
\hline $\begin{array}{l}\text { Multiple measure- } \\
\text { ments }\end{array}$ & Diverse air mass & $\begin{array}{l}\text { AERONET aerosol opti- } \\
\text { cal thickness (AOT) }\end{array}$ & $\begin{array}{l}N_{\mathrm{CCN}} \text { predicted based on } \\
\text { empirical relationship be- } \\
\text { tween AOT and } N_{\mathrm{CCN}} \text { as a } \\
\text { power law. }\end{array}$ & $\begin{array}{l}N_{\mathrm{CCN}} \text { predicted at SS } \\
>0.3 \% \text { with a } 0.88 R^{2} \text {, } \\
\text { but with a factor-of- } 4 \\
\text { range of } N_{\mathrm{CCN}} \text { at a given } \\
\text { AOT. }\end{array}$ & Andreae (2009) \\
\hline Four ARM sites & Polluted air mass & $\begin{array}{l}\text { SSA, backscatter frac- } \\
\text { tion and } \sigma_{\mathrm{sp}}\end{array}$ & $\begin{array}{l}N_{\mathrm{CCN}} \text { estimated from } \\
\text { fitting parameters for the } \\
N_{\mathrm{CCN}} \text { activity spectra, } \\
\text { which can be calculated } \\
\text { based on their empirical } \\
\text { relationships with aerosol } \\
\text { optical properties. }\end{array}$ & $\begin{array}{l}N_{\mathrm{CCN}} \text { predicted with } \\
\text { slopes around } 0.9 \text { and } \\
R^{2} \text { around } 0.6 .\end{array}$ & Jefferson (2010) \\
\hline $\begin{array}{l}\text { Multiple ARM } \\
\text { sites around the } \\
\text { world }\end{array}$ & Diverse air mass & $\begin{array}{l}\mathrm{RH}, f \mathrm{RH}, \mathrm{SSA}, \mathrm{AOT} \\
\text { and } \sigma_{\mathrm{sp}}\end{array}$ & $\begin{array}{l}N_{\mathrm{CCN}} \text { calculated with } \sigma_{\mathrm{sp}} \\
\text { (or AOT) based on their em- } \\
\text { pirical relationship, which } \\
\text { is affected by RH, } f \mathrm{RH} \text { and } \\
\text { SSA. }\end{array}$ & $\begin{array}{l}\text { Best results achieved } \\
\text { by using } \sigma_{\mathrm{sp}} \text { and SSA. } \\
\text { Weak effect on the } \\
\sigma_{\mathrm{sp}}-N_{\mathrm{CCN}} \text { relationship } \\
\text { by } f \mathrm{RH} . N_{\mathrm{CCN}}-\mathrm{AOT} \\
\text { relationship deteriorated } \\
\text { with increasing RH }\end{array}$ & $\begin{array}{l}\text { Liu and } \\
\mathrm{Li}(2014)\end{array}$ \\
\hline $\begin{array}{l}\text { Multiple ARM } \\
\text { sites around the } \\
\text { world }\end{array}$ & $\begin{array}{l}\text { Diverse air mass } \\
\text { not dominated by } \\
\text { dust }\end{array}$ & $\begin{array}{l}\AA \text { and extinction coeffi- } \\
\text { cient }\end{array}$ & $\begin{array}{l}N_{\mathrm{CCN}} \text { calculated with light } \\
\text { extinction based on their } \\
\text { empirical relationship. }\end{array}$ & $\begin{array}{l}\text { Deviated typically } \\
\text { within a factor of } 2.0 .\end{array}$ & $\begin{array}{l}\text { Shinozuka et } \\
\text { al. (2015) }\end{array}$ \\
\hline
\end{tabular}

${ }^{1}$ International Consortium for Atmospheric Research on Transport and Transformation. ${ }^{2}$ Haze in China. ${ }^{3}$ Troposphere Aerosol Radiative Forcing Experiment. ${ }^{4}$ Second Aerosol Characterization Experiment. ${ }^{5}$ Atmospheric Radiation Measurement. ${ }^{6}$ Transport and Chemical Evolution over the Pacific. ${ }^{7}$ Aerosol Characterization Experiment-Asia.

tional measurements of PNSD are needed. For the second, $N_{\mathrm{CCN}}$ is calculated based on statistical relationships between $N_{\mathrm{CCN}}$ and aerosol optical properties, such as scattering coefficient $\left(\sigma_{\mathrm{sp}}\right)$, Ångström exponent $(\AA)$ and single-scattering albedo (SSA; Jefferson, 2010; Shinozuka et al., 2015). $\AA$ is the exponent commonly used to describe the dependence of $\sigma_{\mathrm{sp}}$ on wavelength as the formula shows:

$\sigma_{\mathrm{sp}}(\lambda)=\beta \cdot \lambda^{-\AA}$, 
where $\beta$ is the aerosol number concentration. The coefficient of determination $\left(R^{2}\right)$ between measured and calculated $N_{\mathrm{CCN}}$ using the first method is about 0.9 . For the second method, $R^{2}$ is generally lower than 0.9 , although the instruments are cheaper and easier in operation. Applications similar to the second method are widely used in remote sensing. As shown in Table 1, earlier studies found that the aerosol volume or aerosol PNSD retrieved from remote sensing measurements can be used to calculate $N_{\mathrm{CCN}}$ (Gasso and Hegg, 2003; Kapustin et al., 2006). Recently, either aerosol optical depth (AOD) or aerosol vertical profile has been used to predict $N_{\mathrm{CCN}}$ directly (Ghan and Collins, 2004; Ghan et al., 2006; Andreae, 2009; Liu and Li, 2014).

In the statistical relationship between $N_{\mathrm{CCN}}$ and aerosol optical properties, $\sigma_{\mathrm{sp}}$ or AOD is mainly the proxy of aerosol absolute concentration, while $\AA$ or SSA can be used to reveal the variations of aerosol CCN activity, as shown in Table 1. Based on Köhler theory (Köhler, 1936; Petters and Kreidenweis, 2007), aerosol CCN activity is determined by aerosol size and aerosol chemical composition, and aerosol chemical composition can be defined as aerosol hygroscopicity. Information about aerosol size and aerosol hygroscopicity is critical to $N_{\mathrm{CCN}}$ prediction, and their absence can lead to a deviation by a factor of 4 (Andreae, 2009). Compared with aerosol hygroscopicity, aerosol size is more important in determining CCN activity (Dusek et al., 2006). The value of $\AA$ can provide information on mean predominate aerosol size (Brock et al., 2016; Kuang et al., 2017a). As a result, $N_{\mathrm{CCN}}$ calculation from $\AA$ and the extinction coefficient is found to be accurate to some extent (Shinozuka et al., 2015). As proxies for aerosol hygroscopicity, SSA or aerosol light-scattering enhancement factor $(f \mathrm{RH})$ is commonly used, albeit not so effective (Jefferson, 2010; Liu and Li, 2014). $f$ RH is defined as

$$
f \mathrm{RH}=\sigma_{\mathrm{sp}}(\mathrm{RH}) / \sigma_{\mathrm{sp}},
$$

where $\sigma_{\mathrm{sp}}(\mathrm{RH})$ is the humidified $\sigma_{\mathrm{sp}}$ at a given relative humidity (RH). SSA is determined by the ratio between the light-absorbing carbonaceous and less-absorbing components. Black carbon dominates the absorption of solar radiation and is a main hydrophobic component as well. Lessabsorbing components consist of inorganic salts and acids, as well as most organic compounds, which are generally hygroscopic components. SSA correlates positively with aerosol hygroscopicity (Rose et al., 2010) but deviates significantly due to the diversity of hygroscopicity of less-absorbing components. Thus $N_{\mathrm{CCN}}$ calculation combining SSA, backscatter fraction and $\sigma_{\mathrm{sp}}$ still leads to significant deviations, with $R^{2}=0.6$ (Jefferson, 2010). As for $f \mathrm{RH}$, there was a study that applied aerosol optical quantities $\left(\sigma_{\mathrm{sp}}\right.$ or aerosol optical thickness) with $f \mathrm{RH}$ or SSA to calculate $N_{\mathrm{CCN}}$ (Liu and $\mathrm{Li}, 2014)$. In their study, compared with the combination of SSA and aerosol optical quantities, the combination of $f \mathrm{RH}$ and aerosol optical quantities is found to be less accurate in estimating $N_{\mathrm{CCN}}$, even though $f \mathrm{RH}$ is directly connected with aerosol hygroscopicity (Liu and $\mathrm{Li}, 2014$ ). This may result from the significant dependence of $f \mathrm{RH}$ on aerosol size (Chen et al., 2014; Kreidenweis and Asa-Awuku, 2014; Kuang et al., 2017a). As mentioned before, PNSD is needed for better calculation of $\kappa$ and $N_{\mathrm{CCN}}$ from $f \mathrm{RH}$ in previous studies (Ervens et al., 2007; Chen et al., 2014). A new method to estimate $\kappa$ from $f \mathrm{RH}$ and $\AA$ was proposed recently (Kuang et al., 2017a; Brock et al., 2016). Based on this method, $f \mathrm{RH}$ can be used to calculate $N_{\mathrm{CCN}}$ without measurements of PNSD and can be expected to improve the $N_{\mathrm{CCN}}$ prediction just based on measurements of aerosol optical properties.

In this study, the relationship between $N_{\mathrm{CCN}}$ and aerosol optical properties measured by a humidified nephelometer system is studied and a new method for $N_{\mathrm{CCN}}$ prediction is proposed. This new method is validated based on data observed in the Gucheng campaign on the North China Plain and can be expected to improve measurements of $N_{\mathrm{CCN}}$ due to advantages of applying nephelometers.

\section{Methodology}

\subsection{Data}

Data in this study are mainly measured at Gucheng $\left(39.15^{\circ} \mathrm{N}, 115.74^{\circ} \mathrm{E}\right)$ during autumn in 2016 on the North China Plain. Gucheng is $100 \mathrm{~km}$ southwest from Beijing and $40 \mathrm{~km}$ northeast from Baoding and has background pollution conditions on the North China Plain. The observation site was surrounded by farmland and about $3 \mathrm{~km}$ away from the town of Gucheng. This campaign started on 20 October and lasted for nearly 1 month.

Instruments used in the Gucheng campaign were located in a measurement container under temperature maintained at $25^{\circ} \mathrm{C}$. Ambient aerosol was sampled and dried to RH lower than $30 \%$ by an inlet system consisting of a PM10 inlet, inline Nafion dryers, and a RH and temperature sensor (Vaisala HMP110). Then the sample aerosol was separated by a splitter and directed into various instruments. During this campaign, $\sigma_{\mathrm{sp}}, f \mathrm{RH}$, particle-size-resolved activation ratio (AR) and PNSD were obtained.

$f \mathrm{RH}$ and $\sigma_{\mathrm{sp}}$ at three wavelengths were measured by a humidified nephelometer system consisting of two nephelometers (Aurora 3000, Ecotech Inc.) and a humidifier. In addition, $\AA$ can be calculated directly from $\sigma_{\mathrm{sp}}$ measured by a nephelometer. The humidifier with a Gore-Tex tube humidified the sample air up to $90 \% \mathrm{RH}$. A whole cycle of humidification from 50 to $90 \% \mathrm{RH}$ lasted about $45 \mathrm{~min}$. Dried $\sigma_{\mathrm{sp}}$ was obtained directly from dried sample aerosol measured by one nephelometer, and humidified $\sigma_{\mathrm{sp}}$ was obtained from humidified aerosol measured by another nephelometer. $f \mathrm{RH}$ can be calculated by dividing humidified $\sigma_{\mathrm{sp}}$ by dried $\sigma_{\mathrm{sp}}$. Detailed description of the humidified nephelometer system was illustrated in Kuang et al. (2017a). 
The particle-size-resolved AR, defined as the ratio of $N_{\mathrm{CCN}}$ to total particles at a specific particle size, was measured by a system mainly consisting of a differential mobility analyzer (DMA, model 3081) and a continuous-flow CCN counter (model CCN200, Droplet Measurement Technologies, USA; Roberts and Nenes, 2005; Lance et al., 2006). The system selected mono-disperse particles with the DMA coupled with an electrostatic classifier (model 3080; TSI, Inc., Shoreview, MN USA) and measured AR of the monodisperse particles by a condensation particle counter (CPC model 3776; TSI, Inc.) and CCN counter. Ranges of particle size and supersaturation (SS) were 10-300 $\mathrm{nm}$ and $0.07-$ $0.80 \%$, respectively. Measurements at five supersaturations $(0.07,0.10,0.20,0.40$ and $0.80 \%)$ were conducted sequentially with each cycle lasting for $1 \mathrm{~h}$, and $N_{\mathrm{CCN}}$ at $0.07 \%$ supersaturation was used in this study. Due to non-idealities of the CCN counter at supersaturations lower than $0.10 \%$, $\mathrm{CCN}$ measurement at $0.07 \%$ supersaturation was found to be the most uncertain (Rose et al., 2008) and can lead to deviations of measured $N_{\mathrm{CCN}}$ in this study. Before and after the campaign, supersaturations set in this system were calibrated using ammonium sulfate (Rose et al., 2008). More information about the system is available in Deng et al. (2011) and Ma et al. (2016).

PNSD with a particle diameter from $9 \mathrm{~nm}$ to $10 \mu \mathrm{m}$ was measured by a mobility particle size spectrometer (SMPS, TSI Inc., model 3996) and an aerodynamic particle sizer (APS, TSI Inc., model 3321). SMPS consisted of a DMA, an electrostatic classifier and a CPC (model 3776; TSI, Inc., Shoreview, MN USA) and measured PNSD with a diameter lower than $700 \mathrm{~nm}$.

In addition, PNSD and $\sigma_{\text {sp }}$ from 2011 to 2014 during four campaigns (Wuqing in 2011, Xianghe in 2012 and 2013, and Wangdu in 2014) in the North China Plain were used in this study. PNSD in these campaigns was measured by a twin differential mobility particle sizer (TDMPS, Leibniz Institute for Tropospheric Research (IfT), Germany) and an APS (TSI Inc., model 3321). A TSI 3563 nephelometer was used to obtain $\sigma_{\mathrm{sp}}$ at three wavelengths. Details about the four campaigns can be found in Ma et al. $(2011,2016)$ and Kuang et al. (2016, 2017a).

\subsection{Theories}

Hygroscopic growth of particles at a certain relative humidity can be described by $\kappa$-Köhler theory (Petters and Kreidenweis, 2007):

$$
\frac{\mathrm{RH}}{100}=\frac{g(\mathrm{RH})^{3}-1}{g(\mathrm{RH})^{3}-(1-\kappa)} \cdot \exp \left(\frac{4 \sigma_{\mathrm{s} / \mathrm{a}} \cdot \mathrm{M}_{\mathrm{W}}}{R \cdot T \cdot D_{\mathrm{d}} \cdot g(\mathrm{RH}) \cdot \rho_{\mathrm{w}}}\right),
$$

where $g(\mathrm{RH})$ is the geometric diameter growth factor; $\kappa$ is the hygroscopicity parameter; $\mathrm{RH}$ is the relative humidity; $\rho_{\mathrm{W}}$ is the density of water; $M_{\mathrm{W}}$ is the molecular weight of water; $\sigma_{\mathrm{s} / \mathrm{a}}$ is the surface tension of the solution-air interface, which is assumed to be equal to the surface tension of the pure water-air interface; $R$ is the universal gas constant; and $T$ is the temperature.

When accounting for the impact of $\AA$, $\kappa_{\mathrm{f}}$ can be derived directly from $f$ RH (Brock et al., 2016; Kuang et al., 2017a). A single-parameter parameterization scheme proposed by Brock et al. (2016) connects $f \mathrm{RH}$ and $\kappa$ by the approximately proportional relationship between total aerosol volume and $\sigma_{\mathrm{sp}}$ :

$f(\mathrm{RH})=1+\kappa_{\text {sca }} \times \mathrm{RH} /(100-\mathrm{RH})$,

where $\kappa_{\text {sca }}$ is a parameter for fitting $f$ RH curves and can be used to predict $\kappa_{\mathrm{f}}$ in combination with $\AA$ as in recent studies (Brock et al., 2016; Kuang et al., 2017a). This method of calculating $\kappa_{\mathrm{f}}$ based on $\kappa_{\text {sca }}$ and $\AA$ was confirmed by good agreement with $\kappa_{\mathrm{f}}$ calculated from $f$ RH and PNSD.

$N_{\mathrm{CCN}}$ can be calculated from size-resolved AR at a certain SS and PNSD (referred to as $\left.n\left(\log D_{P}\right)\right)$ as follows:

$N_{\mathrm{CCN}}=\int_{\log D_{\mathrm{P}}} \mathrm{AR}\left(\log D_{\mathrm{P}}, S S\right) \cdot n\left(\log D_{\mathrm{P}}\right) \mathrm{d} \log D_{\mathrm{P}}$.

In general, size-resolved AR curves are complicated and always replaced by a critical diameter $\left(D_{\mathrm{c}}\right)$ to simplify calculation (Deng et al., 2013). The critical diameter is defined as

$N_{\mathrm{CCN}}=\int_{\log D_{\mathrm{c}}}^{\log D_{\mathrm{P}, \max }} n\left(\log D_{\mathrm{P}}\right) \mathrm{d} \log D_{\mathrm{P}}$,

where $D_{\mathrm{P}, \max }$ is the maximum diameter of the measured PNSD. In other words, the integral of PNSD larger than $D_{\mathrm{c}}$ equals the measured $N_{\mathrm{CCN}}$. And a critical $\kappa\left(\kappa_{\mathrm{c}}\right)$ can be calculated by Eq. (3) and indicates CCN activity and hygroscopicity of particles.

\section{Results}

\subsection{Calculation of $N_{\mathrm{CCN}}$ based on measurements of a humidified nephelometer system}

Free of sea salt aerosol and dust aerosol, accumulation mode aerosol dominates both the optical scattering ability at short wavelengths and the $\mathrm{CCN}$ activity at low supersaturations, and thus a reasonable relationship between $\sigma_{\mathrm{sp}}$ and $N_{\mathrm{CCN}}$ can be achieved. Figure 1 shows the size distribution of cumulative contributions of $\sigma_{\mathrm{sp}}$ at $450 \mathrm{~nm}$ and $N_{\mathrm{CCN}}$ at $0.07 \%$ with various $\AA$ and $\kappa_{\mathrm{c}}$, and corresponding normalized PNSDs based on data measured during the four campaigns on the North China Plain. During the four campaigns, no sea salt aerosol or dust aerosol was observed (Ma et al., 2011, 2016; Kuang et al., 2016, 2017a). For continental aerosol without sea salt or dust, $\AA$ varies from 0.5 to 1.8 , and $\kappa_{\mathrm{c}}$ varies from 0.1 to 0.5 (Cheng et al., 2008; Ma et al., 2011; Liu et al., 2014; Kuang et al., 2017b). As mentioned before, $\AA$ can be 


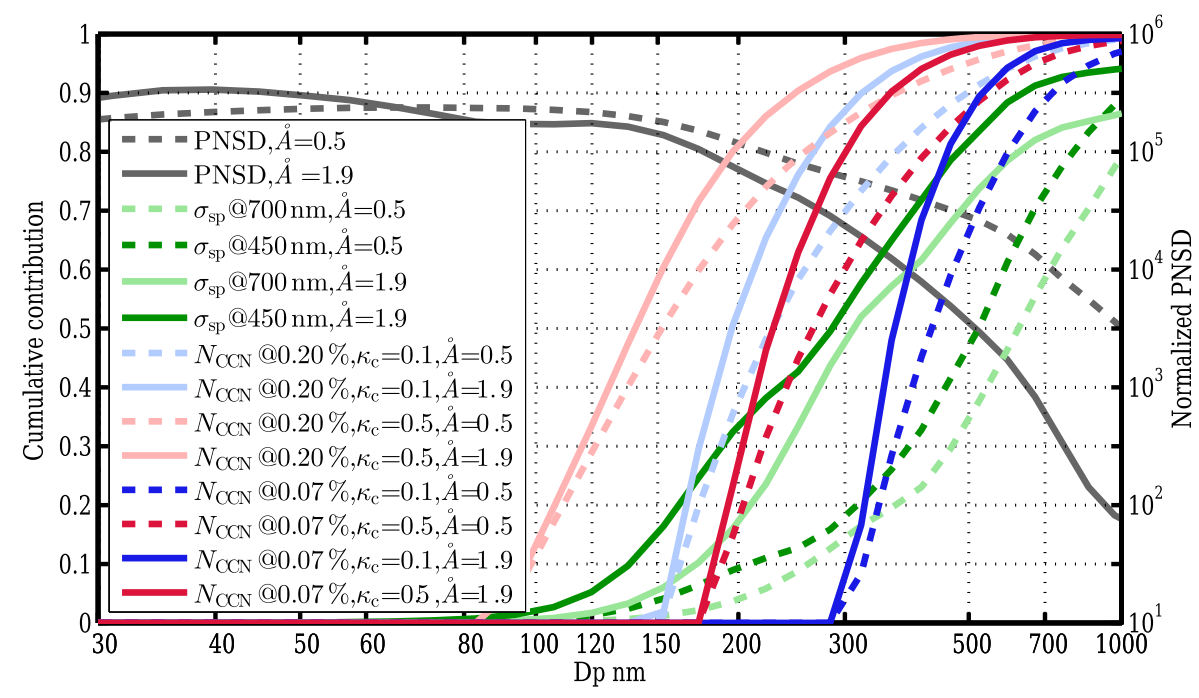

Figure 1. Aerosol PNSD (black lines), the cumulative contribution of $\sigma_{\mathrm{sp}}$ at wavelength of 450 and $700 \mathrm{~nm}$ (dark green lines and light green lines, respectively), the cumulative contribution of $N_{\mathrm{CCN}}$ at a supersaturation of $0.07 \%$ (dark red and dark blue lines) and the cumulative contribution of $N_{\mathrm{CCN}}$ at a supersaturation of $0.20 \%$ (light red and light blue lines) based on measurement in several campaigns in the North China Plain. Solid lines and dashed lines indicate $\AA$ of 1.9 and 0.5 , respectively. Blue lines and red lines indicate $\kappa_{\mathrm{c}}$ of 0.1 and 0.5 , respectively.

used as a proxy of the overall size distribution of aerosol populations, with smaller $\AA$ indicating more larger particles. In Fig. 1, comparisons for $\AA$ are made between 0.5 and 1.9 and for $\kappa_{\mathrm{c}}$ are made between 0.1 and 0.5 . As larger particles contribute more to light scattering and $\mathrm{CCN}$ activation, cumulative contributions of both $\sigma_{\mathrm{sp}}$ and $N_{\mathrm{CCN}}$ increase significantly at the diameter range of accumulation mode particles. Because more hygroscopic particles are able to activate at smaller diameters, the cumulative contribution of $N_{\mathrm{CCN}}$ with higher $\kappa_{\mathrm{c}}$ increases at smaller diameters. In general, major contributions of both $\sigma_{\mathrm{sp}}$ and $N_{\mathrm{CCN}}$ are made by particles from 200 to $500 \mathrm{~nm}$ for various $\AA$ and $\kappa_{\mathrm{c}}$. This implies the feasibility of inferring $N_{\mathrm{CCN}}$ from aerosol optical properties.

Because particles smaller than $200 \mathrm{~nm}$ can activate at supersaturations higher than $0.07 \%$ while scattering less light at wavelengths longer than $450 \mathrm{~nm}$, which are shown as the light-color lines in Fig. 1, it is obvious that significant differences will exist between cumulative contributions of $\sigma_{\mathrm{sp}}$ and $N_{\mathrm{CCN}}$. This means $\sigma_{\mathrm{sp}}$ and $N_{\mathrm{CCN}}$ are dominated by different particles, and poor correlation between $\sigma_{\mathrm{sp}}$ and $N_{\mathrm{CCN}}$ can be expected. Thus the method of inferring $N_{\mathrm{CCN}}$ from aerosol optical properties is applicable for shorter wavelengths and lower supersaturations.

Furthermore, PNSD with higher $\AA$ indicates more Aitken mode particles and fewer accumulation mode particles. Thus large particles contribute less for both $\sigma_{\mathrm{sp}}$ and $N_{\mathrm{CCN}}$ when $\AA$ are higher, characterizing an increase of cumulative contribution curves at smaller diameters. In detail, cumulative contribution curves of $\sigma_{\mathrm{sp}}$ at $1.9 \AA$ are about 0.3 higher than these curves at $0.5 \AA$ in the size range of 200 to $700 \mathrm{~nm}$, while cumulative contribution curves of $N_{\mathrm{CCN}}$ at $1.9 \AA$ are 0.2 no higher than these curves at $0.5 \AA$. Changes of cumulative contributions of $N_{\mathrm{CCN}}$ and $\sigma_{\mathrm{sp}}$ with various $\AA$ reveal that the shape of PNSD can influence the correlation between $N_{\mathrm{CCN}}$ and $\sigma_{\text {sp }}$. This is confirmed by previous studies in which $\AA$ is found to play an important role in calculating $N_{\mathrm{CCN}}$ from $\sigma_{\mathrm{sp}}$ (Shinozuka et al., 2015; Liu and Li, 2014).

The relationship between $\sigma_{\mathrm{sp}}$ and $N_{\mathrm{CCN}}$ dependent on $\AA$ and $\kappa_{\mathrm{c}}$ is evaluated by calculating $\sigma_{\mathrm{sp}}$ and $N_{\mathrm{CCN}}$ with different PNSDs (classified by $\AA$ ) and different $\kappa_{\mathrm{c}}$. In detail, ratios of $N_{\mathrm{CCN}}$ to $\sigma_{\mathrm{sp}}$, referred to as $\mathrm{AR}_{\mathrm{sp}}$, are calculated to eliminate the effect of variations of particle concentrations consistent at all diameters. Results at a supersaturation of $0.07 \%$ are shown in Fig. 2, and $\mathrm{AR}_{\mathrm{sp}}$ is higher than 0 and lower than 10. In general, $\mathrm{AR}_{\mathrm{sp}}$ are higher for more hygroscopic particles or smaller particles. As particles become more hygroscopic, more CCN can be expected when $\sigma_{\mathrm{sp}}$ is fixed. As aerosol populations consist of more smaller $\mathrm{CCN}$-active particles, the increase of $\sigma_{\mathrm{sp}}$ is weaker than that of $N_{\mathrm{CCN}}$. For example, particles with diameters slightly larger than $D_{\mathrm{c}}$ contribute less to $\sigma_{\mathrm{sp}}$ than particles with diameters much larger than $D_{\text {c }}$.

In detail, the sensitivity of $\mathrm{AR}_{\mathrm{sp}}$ to $\AA$ also changes with $\AA$ and $\kappa_{\mathrm{c}}$. When $\AA$ are higher than 1.4 and $\kappa_{\mathrm{c}}$ is lower than 0.2 , $\mathrm{AR}_{\mathrm{sp}}$ is insensitive to $\AA$; while when $\AA$ are lower than 1 and $\kappa_{\mathrm{c}}$ are higher than about $0.3, \mathrm{AR}_{\mathrm{sp}}$ is more sensitive to $\AA$ than $\kappa_{\mathrm{c}}$. This higher sensitivity of $\mathrm{AR}_{\mathrm{sp}}$ to $\AA$ reveals that, if the mean predominate size of particles is smaller, the increase of $N_{\mathrm{CCN}}$ due to the increase of $\AA$ mentioned in the previous paragraph can be larger as a result. This is the consequence of the sensitivity of $A R_{\text {sp }}$ to $\AA$ resulting from the variation of small $\mathrm{CCN}$-active particles, as mentioned before. 


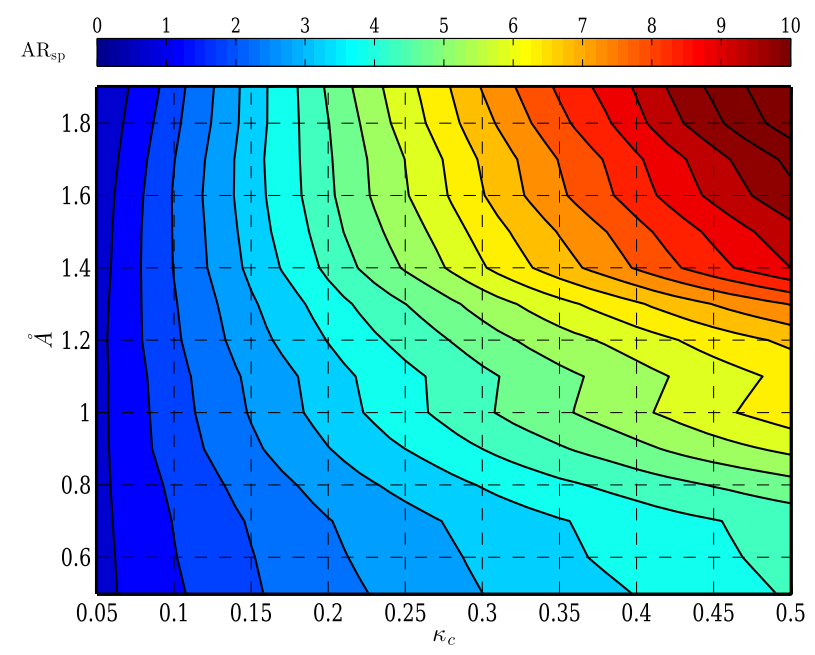

Figure 2. Colors represent $\mathrm{AR}_{\mathrm{sp}}$ (calculated as $\mathrm{AR}_{\mathrm{sp}}=\frac{N_{\mathrm{CCN}}}{\sigma_{\mathrm{sp}}}$ at $450 \mathrm{~nm}$ wavelength and $0.07 \%$ supersaturation) with different PNSDs (classified by $\AA$ values) and different $\kappa_{\mathrm{c}}$.

Based on the lookup table illustrated in Fig. 2, $N_{\mathrm{CCN}}$ at a supersaturation of $0.07 \%$ can be calculated simply from $\AA$, $\kappa_{\mathrm{f}}$ and $\sigma_{\mathrm{sp}}$, which can be obtained from measurements of a three-wavelength humidified nephelometer system. The description of this simple method is shown in Fig. 3. A new lookup table needs to be made for $N_{\mathrm{CCN}}$ estimation at other supersaturations, which should ideally be less than $0.07 \%$ as mentioned in the caption of Fig. 1.

One critical issue about the method is the conversion of the $\kappa_{\mathrm{f}}$ obtained from the humidified nephelometer system to the $\kappa_{\mathrm{c}}$ under supersaturated conditions. There are two main factors making this conversion necessary. First, closure studies of aerosol hygroscopicity found significant deviations between hygroscopicity at sub-saturated conditions and supersaturated conditions (Wex et al., 2009; Irwin et al., 2010; Good et al., 2010; Renbaum-Wolff et al., 2016). Their difference can be expected to be about 0.1 for accumulation mode aerosol (Wu et al., 2013; Whitehead et al., 2014; Ma et al., 2016). Second, $\kappa_{\mathrm{f}}$ indicates the hygroscopicity of total particles and can be quite different from aerosol hygroscopicity at a specific diameter due to variations of size-dependent particle hygroscopicity. Kuang et al. (2017a) found a difference around 0.1 between $\kappa_{\mathrm{f}}$ and $\kappa$ inferred from $g(\mathrm{RH})$ measurements for accumulation mode particles whose $\kappa_{\mathrm{f}}$ is no larger than 0.2. In this study, a simple conversion wherein $\kappa_{\mathrm{c}}$ is 0.2 higher than $\kappa_{\mathrm{f}}$ is used to calculate $N_{\mathrm{CCN}}$, while for $\kappa_{\mathrm{f}}$ larger than 0.2 , a smaller difference of 0.1 between $\kappa_{\mathrm{c}}$ and $\kappa_{\mathrm{f}}$ should be used (Kuang et al., 2017a). This simplified relationship between $\kappa_{\mathrm{c}}$ and $\kappa_{\mathrm{f}}$ is a rough estimate regardless of the complexity of differences of aerosol hygroscopicity measured by different instruments, but it is still used in this study for two reasons. First, the accurate conversion cannot be achieved without detailed information of the particle hygroscopicity, which is difficult and complicated to measure.

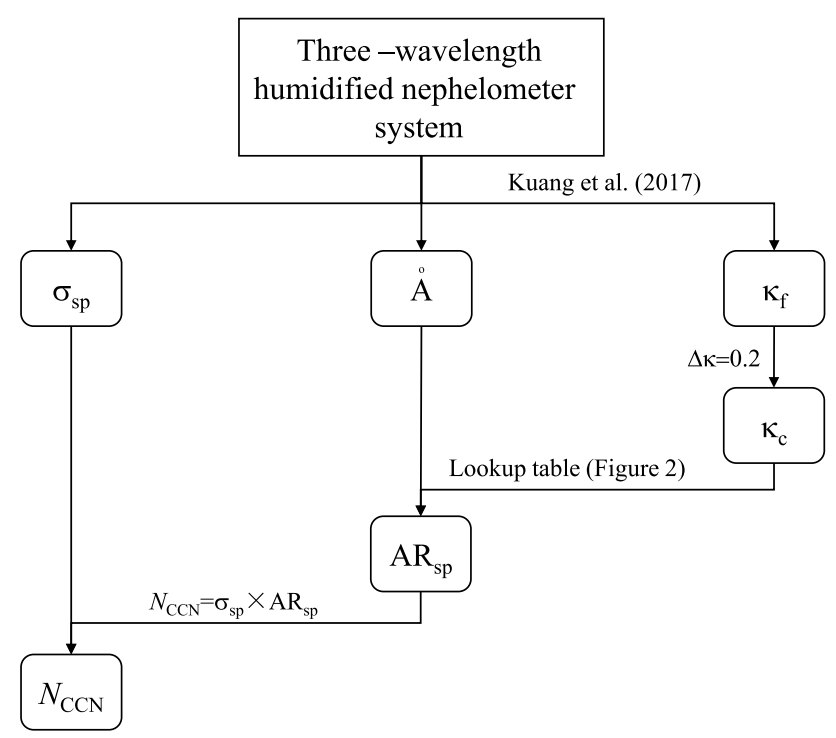

Figure 3. The schematic chart of the $N_{\mathrm{CCN}}$ prediction based on measurements of a humidified nephelometer system.

Second, a deviation of $\kappa_{\mathrm{c}}$ less than 0.1 generally leads to a deviation of $N_{\mathrm{CCN}}$ less than $20 \%$ (Ma et al., 2016), which is comparable with the deviation of $\mathrm{CCN}$ measurements. As a result, for a simple method of $N_{\mathrm{CCN}}$ calculation, this simple conversion is applicable. In addition, it is important to note that the value of the difference between $\kappa_{\mathrm{c}}$ and $\kappa_{\mathrm{f}}$ is also a rough estimate regardless of the complexity of aerosol hygroscopicity under different conditions, and the influence of $\Delta \kappa$ deviation on $N_{\mathrm{CCN}}$ calculation needs to be further examined based on field observation. For fresh aerosol, the actual $\Delta \kappa$ can be too large (about 4 times the $\kappa$ values for some organic components; Wex et al., 2009; Renbaum-Wolff et al., 2016) or too small (nearly zero for inorganic components and black carbon) and thus is not suitable for the application of this method.

Besides aerosol size and hygroscopicity, the aerosol mixing state can also affect aerosol CCN activity. When primary aerosol emissions are strong, aerosol populations are likely to be externally mixed and a realistic treatment of aerosol mixing state is critical for $N_{\mathrm{CCN}}$ calculation (Cubison et al., 2008; Wex et al., 2010). But for regions away from strong aerosol primary emissions, the influence of mixing state on aerosol CCN activity is small and the assumption of internal mixing state is effective for the estimation of $N_{\mathrm{CCN}}$ (Dusek et al., 2006; Deng et al., 2013; Ervens et al., 2010). For regions above the boundary layer where clouds form and measurements of $N_{\mathrm{CCN}}$ are important, aerosol generally tends to be internally mixed when there is no strong vertical transport (McMeeking et al., 2011; Ferrero et al., 2014) and there are no plumes (Moteki and Kondo, 2007; McMeeking et al., 2011). In addition, it should be noted that influences of aerosol hygroscopicity and aerosol size on aerosol $\mathrm{CCN}$ ac- 


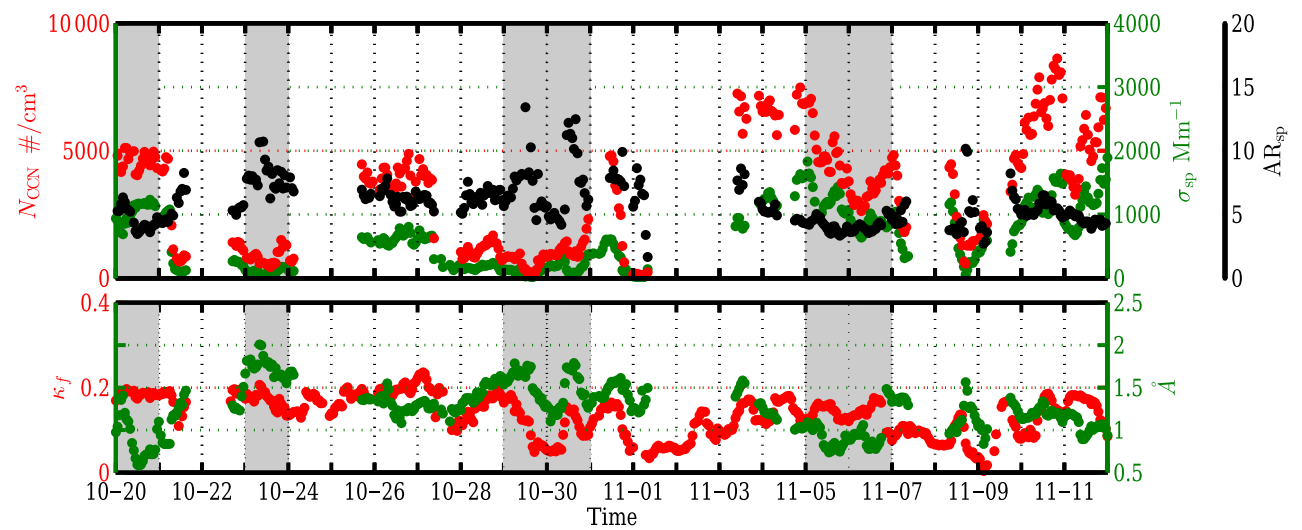

Figure 4. Overview of measurements in Gucheng in 2016. Upper plot: time series of $N_{\mathrm{CCN}}$ at a supersaturation of $0.07 \%$ (red dots); $\sigma_{\mathrm{sp}}$ at the wavelength of $50 \mathrm{~nm}$ (green dots); and their ratios (black dots), referred to as $\mathrm{AR}_{\mathrm{sp}}$. Lower plot: time series of $\kappa_{\mathrm{f}}$ (red dots) and $\AA$ (green dots). The grey bars are periods when the sensitivity of $\mathrm{AR}_{\mathrm{sp}}$ to $\kappa_{\mathrm{c}}$ is notable.
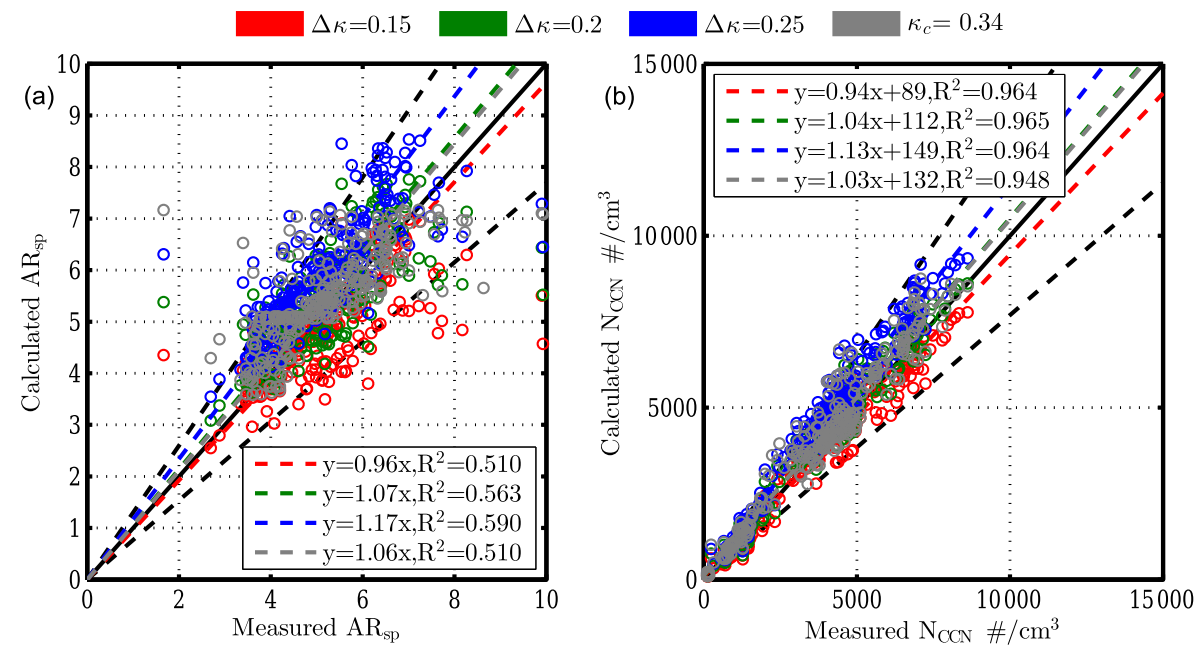

Figure 5. (a) Comparisons of calculated $\mathrm{AR}_{\mathrm{sp}}$ and measured $\mathrm{AR}_{\mathrm{sp}}$ with different conversions of $\kappa_{\mathrm{c}}$ from $\kappa_{\mathrm{f}}$. (b) Regressions of calculated $N_{\mathrm{CCN}}$ and measured $N_{\mathrm{CCN}}$ with different conversions of $\kappa_{\mathrm{c}}$ from $\kappa_{\mathrm{f}}$.

tivity are more significant than the aerosol mixing state and the deviation of $N_{\mathrm{CCN}}$ calculation due to the assumption that the aerosol mixing state is smaller than the deviation due to aerosol size and aerosol hygroscopicity. In the new method of this paper, using $\AA$ and $\kappa_{\mathrm{c}}$ to indicate the influence of aerosol size and aerosol hygroscopicity on aerosol $\mathrm{CCN}$ activity will increase the deviation of $N_{\mathrm{CCN}}$ calculation, which is much larger than the deviation due to the assumption of aerosol mixing state. As a result, the improvement of $N_{\mathrm{CCN}}$ calculation by introducing a more detailed mixing state than internal mixing is limited, and aerosol populations are assumed to be internally mixed for simplification. Thus this method might not be applicable for regions or air masses greatly affected by strong primary aerosol emissions. Furthermore, this new method cannot be applied for regions where sea salt or dust prevails, as mentioned before. In summary, this method can be used to calculate $N_{\mathrm{CCN}}$ for air mass tending to be domi- nated by aged aerosol particles, like continental regions and cloud-forming heights.

\subsection{Validation based on $N_{\mathrm{CCN}}$ measurement}

The method for calculating $N_{\mathrm{CCN}}$ based on measurements of the humidified nephelometer system, including the conversion of $\kappa_{\mathrm{c}}$ and the lookup table, is examined using data measured in Gucheng.

An overview of the data from Gucheng is shown in Fig. 4. From polluted periods to clean periods, significant variations of $N_{\mathrm{CCN}}$ and $\sigma_{\mathrm{sp}}$ can be found, but $\mathrm{AR}_{\mathrm{sp}}$ of $N_{\mathrm{CCN}}$ to $\sigma_{\mathrm{sp}}$ stays around 5 . On 23 an 29 October, $N_{\mathrm{CCN}}$ and $\sigma_{\mathrm{sp}}$ are lower than $2000 \mathrm{\#} \mathrm{cm}^{-3}$ and $500 \mathrm{Mm}^{-1}$, respectively; while on 20, 26 October and 3 November, $N_{\mathrm{CCN}}$ and $\sigma_{\mathrm{sp}}$ are higher than $2000 \mathrm{H} \mathrm{cm}^{-3}$ and $500 \mathrm{Mm}^{-1}$, respectively. These variations of $N_{\mathrm{CCN}}$ and $\sigma_{\mathrm{sp}}$ are mainly due to the variation of the 
particle number concentration rather than the shape of particle size distribution and aerosol hygroscopicity. Variations of $\mathrm{AR}_{\mathrm{sp}}$ result from the variations of $\AA$ and $\kappa_{\mathrm{c}}$, which indicate the variations of aerosol microphysical properties and chemical compositions.

In general, $\mathrm{AR}_{\mathrm{sp}}$ is more sensitive to variations of $\AA$ than $\kappa_{\mathrm{c}}$. As mentioned before, the sensitivity of $\mathrm{AR}_{\mathrm{sp}}$ to $\AA$ is determined by both $\AA$ and $\kappa_{\mathrm{f}}$. In detail, $\AA$ during the campaign mainly ranges from 0.5 to 1.5 , and $\kappa_{\mathrm{f}}$ ranges mainly from 0.05 to 0.2 , which means that $\kappa_{\mathrm{c}}$ ranges from 0.25 to 0.4 . These values of $\AA$ and $\kappa_{\mathrm{f}}$ correspond to a significant sensitivity of $\mathrm{AR}_{\mathrm{sp}}$ to $\AA$, as the lookup table shows in Fig. 2. The sensitivity of $\mathrm{AR}_{\mathrm{sp}}$ to $\kappa_{\mathrm{c}}$ is much smaller and only notable during some short periods (grey bars in Fig. 4). For example, from 5 to 7 November, variations of $\kappa_{\mathrm{f}}$ and $\AA$ are opposite and result in nearly constant $\mathrm{AR}_{\mathrm{sp}}$; from 30 October to 2 November, consistent variations of $\AA$ and $\kappa_{\mathrm{f}}$ lead to greater variations of $\mathrm{AR}_{\mathrm{sp}}$ than other periods. This weak sensitivity of $\mathrm{AR}_{\mathrm{sp}}$ to $\kappa_{\mathrm{f}}$ may be due to the uncertainty of $\kappa_{\mathrm{c}}$ calculated from $\kappa_{\mathrm{f}}$ based on the simplified conversion.

Based on the lookup table of $\kappa_{\mathrm{c}}$ and $\AA$, $\mathrm{AR}_{\mathrm{sp}}$ is calculated and applied to calculate $N_{\mathrm{CCN}}$ with $\sigma_{\mathrm{sp}}$. The calculated $\mathrm{AR}_{\mathrm{sp}}$ and $N_{\mathrm{CCN}}$ are compared with the measured $\mathrm{AR}_{\mathrm{sp}}$ and $N_{\mathrm{CCN}}$, shown as the green dots in Fig. 5. In general, good agreements between calculations and measurements are achieved, and relative deviations are within $30 \%$. For the comparison of $\mathrm{AR}_{\mathrm{sp}}$, the system relative deviation is less than $10 \%$. For the comparison of $N_{\mathrm{CCN}}$, the slope and the correlation coefficient of the regression are 1.03 and 0.966 , respectively.

In addition, the variation of $\Delta \kappa$ and its influence on $\mathrm{AR}_{\mathrm{sp}}$ and $N_{\mathrm{CCN}}$ calculation are studied. As shown in Fig. $6, \Delta \kappa$ is around 0.2 and independent from $\AA$ and $\kappa_{\mathrm{c}}$, and over $80 \%$ of $\Delta \kappa$ ranges from 0.1 to 0.3 . A notable deviation of $\Delta \kappa$ can only be found when $\AA$ is higher than 1.5. High values of $\AA$ represent existences of small particles, which tend to be freshly emitted and experience inefficient aging processes. In this case, this simplified conversion of $\kappa_{\mathrm{c}}$ may not be applicable. Furthermore, $\Delta \kappa$ with different values are applied in the new method to calculate $N_{\mathrm{CCN}}$. In the first way, $\Delta \kappa$ of the $\kappa_{\mathrm{c}}$ conversion is set to be 0.05 higher or lower than 0.2 , which means $\Delta \kappa$ of 0.25 or 0.15 . The corresponding results are presented as the red dots and blue dots in Fig. 5. In the second way, a constant $\kappa_{\mathrm{c}}$ of 0.34 , which is the average of the $\kappa_{\mathrm{c}}$ values in the Gucheng campaign, is used to calculate $\mathrm{AR}_{\mathrm{sp}}$ and $N_{\mathrm{CCN}}$; it is shown as the grey dots in Fig. 5. In general, differences among calculations using various $\kappa_{\mathrm{c}}$ conversions are quite small. The $\Delta \kappa$ difference of 0.05 in $\kappa_{\mathrm{c}}$ conversion only leads to a difference of $10 \%$ for the system relative deviation of calculated $N_{\mathrm{CCN}}$. The correlation coefficient of the calculation using a constant $\kappa_{\mathrm{c}}$ is just a little lower than correlation coefficients of calculations using a $\kappa_{\mathrm{c}}$ conversion. As a result, for data measured in the Gucheng campaign, the method of calculating $N_{\mathrm{CCN}}$ is insensitive to the uncertainty of the $\kappa_{\mathrm{c}}$ conversion, and a $\Delta \kappa$ of 0.2 is applicable in this new method.

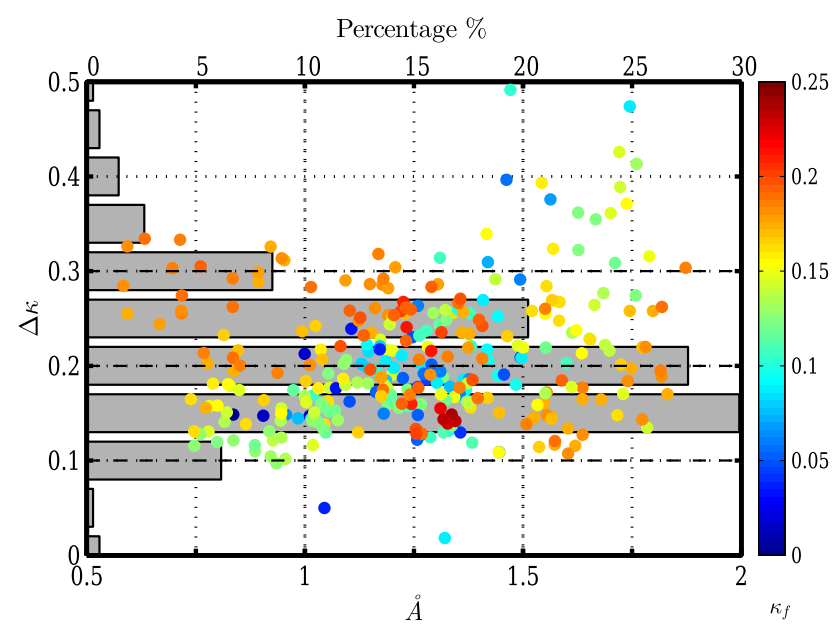

Figure 6. Differences between $\kappa_{\mathrm{c}}$ and $\kappa_{\mathrm{f}}$, referred to as $\Delta \kappa$, with $\AA$ (positions of dots) and $\kappa_{\mathrm{f}}$ (colors of dots). Bars represent percentages of $\Delta \kappa$ within different ranges.

In this study, the insensitivity of calculated $N_{\mathrm{CCN}}-$ to- $\kappa_{\mathrm{C}}$ conversion is partly due to the small variation of $\kappa_{\mathrm{f}}$ during the campaign. However, the variation of $\kappa_{\mathrm{c}}$ can be quite large and cause unignorable deviations of calculated $N_{\mathrm{CCN}}$. As previous studies of $N_{\mathrm{CCN}}$ measurement have shown, the variation of $\kappa_{\mathrm{c}}$ is often small, and a constant $\kappa_{\mathrm{c}}$ can be used to calculate $N_{\mathrm{CCN}}$ accurately (Andreae and Rosenfeld, 2008; Gunthe et al., 2009; Rose et al., 2010; Deng et al., 2013). Results in this study are similar to these previous studies. But large variations of $\kappa_{\mathrm{c}}$ are also found in some other studies. In the North China Plain, fluctuations of aerosol hygroscopicity during new-particle-formation events and soot emissions lead to significant deviations of calculated $N_{\mathrm{CCN}}$ from average aerosol hygroscopicity (Ma et al., 2016). Furthermore, the influence of $\kappa_{\mathrm{c}}$ cannot be ignored because the value of the average hygroscopicity is different in various regions during various periods. In summer of the North China Plain, measured $\kappa_{\mathrm{f}}$ at sub-saturated conditions can reach up to 0.45 when inorganic components dominate in particles (Kuang et al., 2016). In this case, calculated $N_{\mathrm{CCN}}$ ignoring $\kappa_{\mathrm{c}}$ may be 10 times larger than measured $N_{\mathrm{CCN}}$. To sum up, although the exact value of $\kappa_{\mathrm{c}}$ cannot be obtained from the measurement of the humidified nephelometer system, the influence of $\kappa_{\mathrm{c}}$ on $N_{\mathrm{CCN}}$ can be inferred and is found to be correct enough considering the convenience of this method. More data, especially from observations of more hygroscopic aerosol, are still needed to confirm this method. 


\section{Conclusions}

$N_{\mathrm{CCN}}$ is a key parameter of cloud microphysics and aerosol indirect radiative effect. Direct measurements of $N_{\mathrm{CCN}}$ are generally conducted under supersaturated conditions in $\mathrm{CCN}$ chambers, and are complex and costly. Accumulation mode aerosol contributes most to both the aerosol scattering ability and the aerosol CCN activity. In view of this, it is possible to predict $N_{\mathrm{CCN}}$ based on relationships between aerosol optical properties and the aerosol $\mathrm{CCN}$ activity. In this study, a new method is proposed to calculate $N_{\mathrm{CCN}}$ based on measurements of a humidified nephelometer system. In this method, $N_{\mathrm{CCN}}$ is derived from a lookup table which involves $\sigma_{\mathrm{sp}}, \AA$ and $\kappa_{\mathrm{f}}$, and the required three parameters can be obtained from a three-wavelength humidified nephelometer system.

Relationships between aerosol optical properties and aerosol CCN activity are investigated using datasets on aerosol PNSD measured during several campaigns in the North China Plain. The relationship between $\sigma_{\mathrm{sp}}, \AA, \kappa_{\mathrm{c}}$ and $N_{\mathrm{CCN}}$ is analyzed. It is found that the ratio between $N_{\mathrm{CCN}}$ and $\sigma_{\mathrm{sp}}$, referred to as $\mathrm{AR}_{\mathrm{sp}}$, is determined by $\kappa_{\mathrm{c}}$ and $\AA$. In light of this, it is possible to calculate $N_{\mathrm{CCN}}$ based only on measurements of a three-wavelength humidified nephelometer system which provides information about $\sigma_{\mathrm{sp}}$, the hygroscopicity parameter $\kappa$ and $\AA$. However, $\kappa$ derived from measurements of a humidified nephelometer system under sub-saturated conditions (termed $\kappa_{\mathrm{f}}$ ) differs from $\kappa$ under supersaturated conditions, which indicate aerosol CCN activity (termed $\kappa_{\mathrm{c}}$ ). As a result, the conversion from $\kappa_{\mathrm{f}}$ to $\kappa_{\mathrm{c}}$ is needed. Based on previous studies of aerosol hygroscopicity and aerosol CCN activity, a simple conversion from $\kappa_{\mathrm{f}}$ to $\kappa_{\mathrm{c}}$ with a fixed difference (referred to as $\Delta \kappa$ ) of 0.2 is proposed. On the basis of this simple conversion, the method of $N_{\text {CCN }}$ prediction based only on measurements of a humidified nephelometer system is achieved under conditions without sea salt aerosol, dust aerosol, externally mixed aerosol or fresh aerosol.

This method is validated with measurements of a humidified nephelometer system and a CCN counter in Gucheng in 2016. During the campaign, both $N_{\mathrm{CCN}}$ and $\sigma_{\mathrm{sp}}$ vary with the pollution conditions. $\mathrm{AR}_{\mathrm{sp}}$ is around 5 and changes with $\AA$ and $\kappa_{\mathrm{f}}$. Based on this new method, $N_{\mathrm{CCN}}$ are calculated to compare with its measured values. The agreement between the calculated $N_{\mathrm{CCN}}$ and the measured $N_{\mathrm{CCN}}$ is achieved with relative deviations less than $30 \%$. Furthermore, the variation of $\Delta \kappa$ and its influence on $N_{\mathrm{CCN}}$ calculation are studied. The difference between $\kappa_{\mathrm{f}}$ and $\kappa_{\mathrm{c}}$ was $0.2 \pm 0.1$. Sensitivity of calculated $N_{\mathrm{CCN}}$ to conversions from $\kappa_{\mathrm{f}}$ to $\kappa_{\mathrm{c}}$ is studied by applying different kinds of conversions. Results show that calculated $N_{\mathrm{CCN}}$ varies little and is insensitive to the conversions, which confirms the robustness and applicability of this newly proposed method.

This study has connected aerosol optical properties with $N_{\mathrm{CCN}}$ and also proposed a novel method to calculate $N_{\mathrm{CCN}}$ based only on measurements of a three-wavelength humidi- fied nephelometer system. Due to the simple operation and stability of the humidified nephelometer system, this method will facilitate the real-time monitoring of $N_{\mathrm{CCN}}$, especially on aircrafts. In addition, measurements of the widely used CCN counter are limited to supersaturations higher than 0.07. In fogs and shallow layer clouds, supersaturations are generally smaller than $0.1 \%$ (Ditas et al., 2012; Hammer et al., 2014a, b; Krüger et al., 2014). For studying aerosol-cloud interaction, this method is more applicable due to its applicability for calculating $N_{\mathrm{CCN}}$ at lower supersaturations than $1.0 \%$.

Data availability. The corresponding data in Fig. 2 can be accessed through the following link: https://pan.baidu.com/s/1mjyQ8uk. The whole dataset can be accessed by request to the corresponding author.

Competing interests. The authors declare that they have no conflict of interest.

Acknowledgements. This work was supported by the National Natural Science Foundation of China (41590872 and 41505107).

Edited by: Pierre Herckes

Reviewed by: two anonymous referees

\section{References}

Andreae, M. O.: Correlation between cloud condensation nuclei concentration and aerosol optical thickness in remote and polluted regions, Atmos. Chem. Phys., 9, 543-556, https://doi.org/10.5194/acp-9-543-2009, 2009.

Andreae, M. O. and Rosenfeld, D.: Aerosol-cloudprecipitation interactions. Part 1 . The nature and sources of cloud-active aerosols, Earth-Sci. Rev., 89, 13-41, https://doi.org/10.1016/j.earscirev.2008.03.001, 2008.

Brock, C. A., Wagner, N. L., Anderson, B. E., Attwood, A. R., Beyersdorf, A., Campuzano-Jost, P., Carlton, A. G., Day, D. A., Diskin, G. S., Gordon, T. D., Jimenez, J. L., Lack, D. A., Liao, J., Markovic, M. Z., Middlebrook, A. M., Ng, N. L., Perring, A. E., Richardson, M. S., Schwarz, J. P., Washenfelder, R. A., Welti, A., Xu, L., Ziemba, L. D., and Murphy, D. M.: Aerosol optical properties in the southeastern United States in summer - Part 1: Hygroscopic growth, Atmos. Chem. Phys., 16, 49875007, https://doi.org/10.5194/acp-16-4987-2016, 2016.

Chen, J., Zhao, C. S., Ma, N., and Yan, P.: Aerosol hygroscopicity parameter derived from the light scattering enhancement factor measurements in the North China Plain, Atmos. Chem. Phys., 14, 8105-8118, https://doi.org/10.5194/acp-14-8105-2014, 2014.

Cheng, Y. F., Wiedensohler, A., Eichler, H., Su, H., Gnauk, T., Brueggemann, E., Herrmann, H., Heintzenberg, J., Slanina, J., Tuch, T., Hu, M., and Zhang, Y. H.: Aerosol optical properties and related chemical apportionment at Xinken in 
Pearl River Delta of China, Atmos. Environ., 42, 6351-6372, https://doi.org/10.1016/j.atmosenv.2008.02.034, 2008.

Covert, D. S., Charlson, R., and Ahlquist, N.: A study of the relationship of chemical composition and humidity to light scattering by aerosols, J. Appl. Meteorol., 11, 968-976, 1972.

Cubison, M. J., Ervens, B., Feingold, G., Docherty, K. S., Ulbrich, I. M., Shields, L., Prather, K., Hering, S., and Jimenez, J. L.: The influence of chemical composition and mixing state of Los Angeles urban aerosol on CCN number and cloud properties, Atmos. Chem. Phys., 8, 5649-5667, https://doi.org/10.5194/acp-8-56492008, 2008.

Deng, Z. Z., Zhao, C. S., Ma, N., Liu, P. F., Ran, L., Xu, W. Y., Chen, J., Liang, Z., Liang, S., Huang, M. Y., Ma, X. C., Zhang, Q., Quan, J. N., Yan, P., Henning, S., Mildenberger, K., Sommerhage, E., Schäfer, M., Stratmann, F., and Wiedensohler, A.: Size-resolved and bulk activation properties of aerosols in the North China Plain, Atmos. Chem. Phys., 11, 3835-3846, https://doi.org/10.5194/acp-11-3835-2011, 2011.

Deng, Z. Z., Zhao, C. S., Ma, N., Ran, L., Zhou, G. Q., Lu, D. R., and Zhou, X. J.: An examination of parameterizations for the CCN number concentration based on in situ measurements of aerosol activation properties in the North China Plain, Atmos. Chem. Phys., 13, 6227-6237, https://doi.org/10.5194/acp13-6227-2013, 2013.

Ditas, F., Shaw, R. A., Siebert, H., Simmel, M., Wehner, B., and Wiedensohler, A.: Aerosols-cloud microphysicsthermodynamics-turbulence: evaluating supersaturation in a marine stratocumulus cloud, Atmos. Chem. Phys., 12, 2459-2468, https://doi.org/10.5194/acp-12-2459-2012, 2012.

Dusek, U., Frank, G., Hildebrandt, L., Curtius, J., Schneider, J., Walter, S., Chand, D., Drewnick, F., Hings, S., and Jung, D.: Size matters more than chemistry for cloud-nucleating ability of aerosol particles, Science, 312, 1375-1378, 2006.

Ervens, B., Cubison, M., Andrews, E., Feingold, G., Ogren, J. A., Jimenez, J. L., DeCarlo, P., and Nenes, A.: Prediction of cloud condensation nucleus number concentration using measurements of aerosol size distributions and composition and light scattering enhancement due to humidity, J. Geophys. Res.-Atmos., 112, D10S32, https://doi.org/10.1029/2006jd007426, 2007.

Ervens, B., Cubison, M. J., Andrews, E., Feingold, G., Ogren, J. A., Jimenez, J. L., Quinn, P. K., Bates, T. S., Wang, J., Zhang, Q., Coe, H., Flynn, M., and Allan, J. D.: CCN predictions using simplified assumptions of organic aerosol composition and mixing state: a synthesis from six different locations, Atmos. Chem. Phys., 10, 4795-4807, https://doi.org/10.5194/acp10-4795-2010, 2010.

Ferrero, L., Castelli, M., Ferrini, B. S., Moscatelli, M., Perrone, M. G., Sangiorgi, G., D’Angelo, L., Rovelli, G., Moroni, B., Scardazza, F., Mocnik, G., Bolzacchini, E., Petitta, M., and Cappelletti, D.: Impact of black carbon aerosol over Italian basin valleys: high-resolution measurements along vertical profiles, radiative forcing and heating rate, Atmos. Chem. Phys., 14, 96419664, https://doi.org/10.5194/acp-14-9641-2014, 2014.

Gasso, S. and Hegg, D. A.: On the retrieval of columnar aerosol mass and CCN concentration by MODIS, J. Geophys. Res.Atmos., 108, 4010, https://doi.org/10.1029/2002jd002382, 2003.

Ghan, S. J. and Collins, D. R.: Use of in situ data to test a Raman lidar-based cloud condensation nuclei remote sensing method, J. Atmos. Ocean.
Tech., 21, 387-394, https://doi.org/10.1175/1520 0426(2004)021<0387:uoisdt>2.0.co; 2, 2004.

Ghan, S. J., Rissman, T. A., Elleman, R., Ferrare, R. A., Turner, D., Flynn, C., Wang, J., Ogren, J., Hudson, J., Jonsson, H. H., VanReken, T., Flagan, R. C., and Seinfeld, J. H.: Use of in situ cloud condensation nuclei, extinction, and aerosol size distribution measurements to test a method for retrieving cloud condensation nuclei profiles from surface measurements, J. Geophys. Res.Atmos., 111, D05s10, https://doi.org/10.1029/2004jd005752, 2006.

Good, N., Topping, D. O., Allan, J. D., Flynn, M., Fuentes, E., Irwin, M., Williams, P. I., Coe, H., and McFiggans, G.: Consistency between parameterisations of aerosol hygroscopicity and CCN activity during the RHaMBLe discovery cruise, Atmos. Chem. Phys., 10, 3189-3203, https://doi.org/10.5194/acp10-3189-2010, 2010.

Gunthe, S. S., King, S. M., Rose, D., Chen, Q., Roldin, P., Farmer, D. K., Jimenez, J. L., Artaxo, P., Andreae, M. O., Martin, S. T., and Pöschl, U.: Cloud condensation nuclei in pristine tropical rainforest air of Amazonia: size-resolved measurements and modeling of atmospheric aerosol composition and CCN activity, Atmos. Chem. Phys., 9, 7551-7575, https://doi.org/10.5194/acp9-7551-2009, 2009.

Hudson, J. G.: An instantaneous cen spectrometer, J. Atmos. Ocean. Tech., 6, 1055-1065, https://doi.org/10.1175/15200426(1989)006<1055:aics>2.0.co;2, 1989.

Hammer, E., Bukowiecki, N., Gysel, M., Jurányi, Z., Hoyle, C. R., Vogt, R., Baltensperger, U., and Weingartner, E.: Investigation of the effective peak supersaturation for liquid-phase clouds at the high-alpine site Jungfraujoch, Switzerland (3580 ma.s.1.), Atmos. Chem. Phys., 14, 1123-1139, https://doi.org/10.5194/acp14-1123-2014, 2014a.

Hammer, E., Gysel, M., Roberts, G. C., Elias, T., Hofer, J., Hoyle, C. R., Bukowiecki, N., Dupont, J.-C., Burnet, F., Baltensperger, U., and Weingartner, E.: Size-dependent particle activation properties in fog during the ParisFog 2012/13 field campaign, Atmos. Chem. Phys., 14, 10517-10533, https://doi.org/10.5194/acp-1410517-2014, 2014b.

Irwin, M., Good, N., Crosier, J., Choularton, T. W., and McFiggans, G.: Reconciliation of measurements of hygroscopic growth and critical supersaturation of aerosol particles in central Germany, Atmos. Chem. Phys., 10, 11737-11752, https://doi.org/10.5194/acp-10-11737-2010, 2010.

Jefferson, A.: Empirical estimates of CCN from aerosol optical properties at four remote sites, Atmos. Chem. Phys., 10, 68556861, https://doi.org/10.5194/acp-10-6855-2010, 2010.

Kapustin, V. N., Clarke, A. D., Shinozuka, Y., Howell, S., Brekhovskikh, V., Nakajima, T., and Higurashi, A.: On the determination of a cloud condensation nuclei from satellite: Challenges and possibilities, J. Geophys. Res.-Atmos., 111, D04202, https://doi.org/10.1029/2004jd005527, 2006.

Köhler, H.: The nucleus in and the growth of hygroscopic droplets, T. Faraday Soc., 32, 1152-1161, 1936.

Kreidenweis, S. M. and Asa-Awuku, A.: 5.13 - Aerosol Hygroscopicity: Particle Water Content and Its Role in Atmospheric Processes A2 - Holland, Heinrich D, in: Treatise on Geochemistry, 2nd Edn., edited by: Turekian, K. K., Elsevier, Oxford, 331-361, 2014. 
Krüger, M. L., Mertes, S., Klimach, T., Cheng, Y. F., Su, H., Schneider, J., Andreae, M. O., Pöschl, U., and Rose, D.: Assessment of cloud supersaturation by size-resolved aerosol particle and cloud condensation nuclei (CCN) measurements, Atmos. Meas. Tech., 7, 2615-2629, https://doi.org/10.5194/amt-7-2615-2014, 2014.

Kuang, Y., Zhao, C. S., Ma, N., Liu, H. J., Bian, Y. X., Tao, J. C., and $\mathrm{Hu}, \mathrm{M}$.: Deliquescent phenomena of ambient aerosols on the North China Plain, Geophys. Res. Lett., 43, 8744-8750, https://doi.org/10.1002/2016g1070273, 2016.

Kuang, Y., Zhao, C., Tao, J., Bian, Y., Ma, N., and Zhao, G.: A novel method for deriving the aerosol hygroscopicity parameter based only on measurements from a humidified nephelometer system, Atmos. Chem. Phys., 17, 6651-6662, https://doi.org/10.5194/acp-17-6651-2017, 2017a.

Kuang, Y., Zhao, C., Tao, J., Bian, Y., Ma, N., and Zhao, G.: A novel method for deriving the aerosol hygroscopicity parameter based only on measurements from a humidified nephelometer system, Atmos. Chem. Phys., 17, 6651-6662, https://doi.org/10.5194/acp-17-6651-2017, 2017b.

Lance, S., Nenes, A., Medina, J., and Smith, J.: Mapping the operation of the DMT continuous flow CCN counter, Aerosol Sci. Tech., 40, 242-254, 2006.

Lathem, T. L. and Nenes, A.: Water Vapor Depletion in the DMT Continuous-Flow CCN Chamber: Effects on Supersaturation and Droplet Growth, Aerosol Sci. Tech., 45, 604-615, https://doi.org/10.1080/02786826.2010.551146, 2011.

Liu, H. J., Zhao, C. S., Nekat, B., Ma, N., Wiedensohler, A., van Pinxteren, D., Spindler, G., Müller, K., and Herrmann, H.: Aerosol hygroscopicity derived from size-segregated chemical composition and its parameterization in the North China Plain, Atmos. Chem. Phys., 14, 2525-2539, https://doi.org/10.5194/acp-14-2525-2014, 2014.

Liu, J. and Li, Z.: Estimation of cloud condensation nuclei concentration from aerosol optical quantities: influential factors and uncertainties, Atmos. Chem. Phys., 14, 471-483, https://doi.org/10.5194/acp-14-471-2014, 2014.

Ma, N., Zhao, C. S., Nowak, A., Müller, T., Pfeifer, S., Cheng, Y. F., Deng, Z. Z., Liu, P. F., Xu, W. Y., Ran, L., Yan, P., Göbel, T., Hallbauer, E., Mildenberger, K., Henning, S., Yu, J., Chen, L. L., Zhou, X. J., Stratmann, F., and Wiedensohler, A.: Aerosol optical properties in the North China Plain during HaChi campaign: an in-situ optical closure study, Atmos. Chem. Phys., 11, 5959-5973, https://doi.org/10.5194/acp-11-5959-2011, 2011.

Ma, N., Zhao, C., Tao, J., Wu, Z., Kecorius, S., Wang, Z., Größ, J., Liu, H., Bian, Y., Kuang, Y., Teich, M., Spindler, G., Müller, K., van Pinxteren, D., Herrmann, H., Hu, M., and Wiedensohler, A.: Variation of $\mathrm{CCN}$ activity during new particle formation events in the North China Plain, Atmos. Chem. Phys., 16, 8593-8607, https://doi.org/10.5194/acp-16-8593-2016, 2016.

McMeeking, G. R., Morgan, W. T., Flynn, M., Highwood, E. J., Turnbull, K., Haywood, J., and Coe, H.: Black carbon aerosol mixing state, organic aerosols and aerosol optical properties over the United Kingdom, Atmos. Chem. Phys., 11, 9037-9052, https://doi.org/10.5194/acp-11-9037-2011, 2011.
Moteki, N. and Kondo, Y.: Effects of Mixing State on Black Carbon Measurements by Laser-Induced Incandescence, Aerosol Sci. Tech., 41, 398-417, https://doi.org/10.1080/02786820701199728, 2007.

Nenes, A., Chuang, P. Y., Flagan, R. C., and Seinfeld, J. H.: A theoretical analysis of cloud condensation nucleus (CCN) instruments, J. Geophys. Res.-Atmos., 106, 3449-3474, https://doi.org/10.1029/2000jd900614, 2001.

Petters, M. D. and Kreidenweis, S. M.: A single parameter representation of hygroscopic growth and cloud condensation nucleus activity, Atmos. Chem. Phys., 7, 1961-1971, https://doi.org/10.5194/acp-7-1961-2007, 2007.

Roberts, G. and Nenes, A.: A continuous-flow streamwise thermalgradient CCN chamber for atmospheric measurements, Aerosol Sci. Tech., 39, 206-221, 2005.

Rose, D., Gunthe, S. S., Mikhailov, E., Frank, G. P., Dusek, U., Andreae, M. O., and Pöschl, U.: Calibration and measurement uncertainties of a continuous-flow cloud condensation nuclei counter (DMT-CCNC): CCN activation of ammonium sulfate and sodium chloride aerosol particles in theory and experiment, Atmos. Chem. Phys., 8, 1153-1179, https://doi.org/10.5194/acp8-1153-2008, 2008.

Rose, D., Nowak, A., Achtert, P., Wiedensohler, A., Hu, M., Shao, M., Zhang, Y., Andreae, M. O., and Pöschl, U.: Cloud condensation nuclei in polluted air and biomass burning smoke near the mega-city Guangzhou, China - Part 1: Size-resolved measurements and implications for the modeling of aerosol particle hygroscopicity and CCN activity, Atmos. Chem. Phys., 10, 33653383, https://doi.org/10.5194/acp-10-3365-2010, 2010.

Renbaum-Wolff, L., Song, M., Marcolli, C., Zhang, Y., Liu, P. F., Grayson, J. W., Geiger, F. M., Martin, S. T., and Bertram, A. K.: Observations and implications of liquid-liquid phase separation at high relative humidities in secondary organic material produced by $\alpha$-pinene ozonolysis without inorganic salts, Atmos. Chem. Phys., 16, 7969-7979, https://doi.org/10.5194/acp16-7969-2016, 2016.

Shinozuka, Y., Clarke, A. D., Nenes, A., Jefferson, A., Wood, R., McNaughton, C. S., Ström, J., Tunved, P., Redemann, J., Thornhill, K. L., Moore, R. H., Lathem, T. L., Lin, J. J., and Yoon, Y. J.: The relationship between cloud condensation nuclei $(\mathrm{CCN})$ concentration and light extinction of dried particles: indications of underlying aerosol processes and implications for satellitebased CCN estimates, Atmos. Chem. Phys., 15, 7585-7604, https://doi.org/10.5194/acp-15-7585-2015, 2015.

Titos, G., Cazorla, A., Zieger, P., Andrews, E., Lyamani, H., Granados-Muñoz, M. J., Olmo, F. J., and AladosArboledas, L.: Effect of hygroscopic growth on the aerosol light-scattering coefficient: A review of measurements, techniques and error sources, Atmos. Environ., 141, 494-507, https://doi.org/10.1016/j.atmosenv.2016.07.021, 2016.

Wex, H., McFiggans, G., Henning, S., and Stratmann, F.: Influence of the external mixing state of atmospheric aerosol on derived CCN number concentrations, Geophys. Res. Lett., 37, L10805, https://doi.org/10.1029/2010g1043337, 2010. 
Whitehead, J. D., Irwin, M., Allan, J. D., Good, N., and McFiggans, G.: A meta-analysis of particle water uptake reconciliation studies, Atmos. Chem. Phys., 14, 11833-11841, https://doi.org/10.5194/acp-14-11833-2014, 2014.

Wu, Z. J., Poulain, L., Henning, S., Dieckmann, K., Birmili, W., Merkel, M., van Pinxteren, D., Spindler, G., Müller, K., Stratmann, F., Herrmann, H., and Wiedensohler, A.: Relating particle hygroscopicity and $\mathrm{CCN}$ activity to chemical composition during the HCCT-2010 field campaign, Atmos. Chem. Phys., 13, 79837996, https://doi.org/10.5194/acp-13-7983-2013, 2013. 